\title{
Effects of sweating on distal skin temperature prediction during walking
}

\author{
Stephanie Veselá ${ }^{*}$, Boris RM Kingma², Arjan JH Frijns ${ }^{1}$ \\ From 15th International Conference on Environmental Ergonomics (ICEE XV) \\ Portsmouth, UK. 28 June - 3 July 2015
}

\section{Introduction}

Thermal sensation models require a high quality prediction of local skin temperatures $\left(\mathrm{T}_{\text {skin, } \mathrm{X}}\right)$ from thermoregulation models. However, most thermoregulation models are validated for $\mathrm{T}_{\text {skin,mean }}$ under laboratory setting. The objective of this study is to investigate the challenges of simulating distal skin temperatures $\mathrm{T}_{\text {skin,distal }}$ during walking.

\section{Methods}

For this study, the skin temperature $\left(\mathrm{T}_{\text {skin }}\right)$ of human subjects ( 4 males, 2 females) is measured at 15 sites (locations according to [1] plus fingertip) while walking indoors $(2.8 \mathrm{met})$. The subjects wear an everyday outfit consisting of underwear, jeans, T-shirt, long-sleeved shirt, socks and shoes ( 0.8 clo) [2]. The temperature is recorded every 60 seconds during a one hour experiment. The measured data is then compared to the computed $\mathrm{T}_{\text {skin, } \mathrm{X}}$ of the mathematical thermoregulation model ThermoSEM [3].

\section{Results}

The computed $\mathrm{T}_{\text {skin,mean }}$ are within $2{ }^{\circ} \mathrm{C}$ of the measured temperatures. The measured $\mathrm{T}_{\text {skin,foot }}$ range from $29{ }^{\circ} \mathrm{C}$ to $34{ }^{\circ} \mathrm{C}$ for all subjects with an increase of $2-3{ }^{\circ} \mathrm{C}$ in the course of one hour walking. The computed $\mathrm{T}_{\text {skin, }}$ foot largely underestimate the measured values by 4 to 9 ${ }^{\circ} \mathrm{C}$ (Figure 1, light blue squares). For $\mathrm{T}_{\text {skin,hand }}$ it differs only 1 to $4{ }^{\circ} \mathrm{C}$. The clothing insulation and metabolic activity are estimates and might differ from reality. By raising the clothing insulation at the foot to a maximal measured value of 2 clo (see [2]) the computed temperatures increase by $3{ }^{\circ} \mathrm{C}$ (Figure 1, green crosses). The increase of metabolic rate leads to slightly lower computed

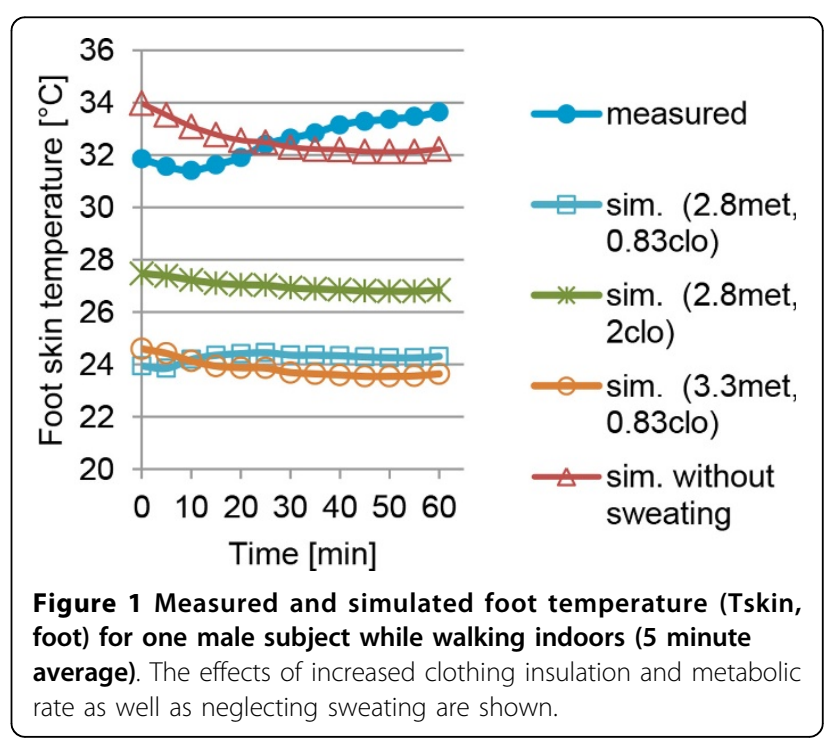

$\mathrm{T}_{\text {skin,foot }}$ (Figure 1, orange circles). Lower $\mathrm{T}_{\text {skin,foot }}$ at increased metabolic rate is due to evaporative heat losses over the entire body because of sweating. If the sweating is neglected in the model, the computed and measured results are in better agreement (Figure 1, red triangles).

\section{Discussion}

Even though the exclusion of sweating leads to improved results for $T_{\text {skin,foot }}$, the main issue is the latent heat transport from the foot skin surface to the environment. The current clothing model only includes a total evaporative resistance taken from [4] due to the absence of studies on detailed local evaporative resistances. Therefore new experiments on local (evaporative) clothing resistances are needed.

* Correspondence: s.vesela@tue.nl

${ }^{1}$ Eindhoven University of Technology, Eindhoven, The Netherlands

Full list of author information is available at the end of the article 


\section{Conclusions}

In order to account for the reduced heat losses when wearing vapour resistant clothing (e.g. shoes), clothing models should differ between sensible and latent heat transport from the skin to the clothing and from the clothing to the environment. Furthermore, experiments are required to quantify the local evaporative resistances more accurately.

\section{Authors' details}

'Eindhoven University of Technology, Eindhoven, The Netherlands. ${ }^{2}$ NUTRIM School, Maastricht University Medical Center, The Netherlands.

Published: 14 September 2015

\section{References}

1. ISO: EN-ISO 9886. Ergonomics - evaluation of thermal strain by physiological measurements. 2004

2. Lee J, Zhang H, Arens E: Typical Clothing Ensemble Insulation Levels for Sixteen Body Parts. In CLIMA Conference 2013-9.

3. Kingma BRM, et al: Incorporating neurophysiological concepts in mathematical thermoregulation models. Int I Biometeorol 2014, 58:87-99.

4. ISO: EN-ISO 9920. Ergonomics of the thermal environment - Estimation of the thermal insulation and water vapour resistance of a clothing ensemble. 2007.

doi:10.1186/2046-7648-4-S1-A31

Cite this article as: Veselá et al:: Effects of sweating on distal skin temperature prediction during walking. Extreme Physiology \& Medicine 2015 4(Suppl 1):A31.

\section{Submit your next manuscript to BioMed Central} and take full advantage of:

- Convenient online submission

- Thorough peer review

- No space constraints or color figure charges

- Immediate publication on acceptance

- Inclusion in PubMed, CAS, Scopus and Google Scholar

- Research which is freely available for redistribution

Submit your manuscript at www.biomedcentral.com/submit 